\title{
CITIZEN SOLDIERS: THE NORTH CAROLINA VOLUNTEERS AND THE WAR ON POVERTY
}

\author{
ROBERT R. KORSTAD* AND JAMES L. LELOUDIS**
}

\section{INTRODUCTION}

During the summers of 1964 and 1965, more than 300 college studentsblack and white, men and women-fanned out across the state of North Carolina in a bold campaign to defeat poverty and, as they saw it, to uplift the poor. They were the foot soldiers of the North Carolina Fund ("Fund"), a pacesetting antipoverty program of the 1960s. The story of those students and their summers of service is important to recount for many reasons, but most especially because it highlights the potential of volunteerism for expanding the boundaries of democratic participation. That point was driven home for us several years ago when we were approached by a number of young people who were active in the community service movement, that broad-based volunteer effort initiated during the 1980s by college and high school students who were eager to develop modes of social action appropriate to the challenges of their own time and generation. The young people who came to us all had demonstrated a remarkable capacity for leadership — they included the founders of such groups as the Campus Outreach Opportunity League, ${ }^{1}$ Public Allies, ${ }^{2}$ and Empty the Shelters - but they also complained of feeling they were laboring in isolation. How, they wondered, might the past inform

Copyright $@ 2000$ by Robert R. Korstad and James L. Leloudis

This article is also available at http://www.law.duke.edu/journals/62LCPKorstad.

* Assistant Professor, Sanford Institute of Public Policy, Duke University.

** Associate Professor, Department of History, University of North Carolina at Chapel Hill.

1. Julia Scatliff helped to develop the Campus Outreach Opportunity League, which coordinates community service programs at colleges and universities around the country. See A Trek for Voluntarism Links Campus Projects, N.Y. TIMES, Sept. 1, 1985, at 50; see also Elizabeth Lenhard, Committed to Community, ATLANTA J. CONST., Mar. 10, 1996, at M3.

2. Jason Scott was one of the founders of Public Allies, an organization that "identifies a diversity of talented young adults and creates opportunities for them to practice leadership and strengthen their communities in a new alliance with people from neighborhoods, non-profits, business and government." See Public Allies: What We Do (visited Feb. 9, 2000) <http:// www.publicallies.org/about.htm>.

3. Claudia Horwitz helped found Empty the Shelters in 1991 while a student at the University of Pennsylvania. Empty the Shelters works with young people around the country to teach them to become advocates for the homeless. See Claudia Horwitz, What is Wrong with National Service?, 24 SOC. POL'Y 37, 39-41 (1993). 
contemporary efforts to take their work beyond the walls of the university, to move students from service to broader civic engagement, and to build new alliances to address enduring social problems: poverty, homelessness, illiteracy, and racial inequality?

Since that encounter, much of our research on the North Carolina Fund and its student volunteers has focused on trying to answer that question. In this article, we trace the history of the Fund's Volunteers program, provide an analysis of the contribution that those students made to fighting poverty in North Carolina, and evaluate the impact of that experience on the lives of the Volunteers themselves. We also consider more broadly the role that the North Carolina Fund played in shaping national antipoverty policy.

II

\section{THE ESTABLISHMENT OF THE NORTH CAROLINA FUND}

The Fund was established in 1963 by Governor Terry Sanford, who had been elected with President John F. Kennedy. When Sanford took office in 1961, North Carolina's factory workers earned some of the lowest industrial wages in the nation; thirty-seven percent of the state's residents had incomes below the federal poverty line; half of all students dropped out of school before obtaining a high school diploma; and one-fourth of adults twenty-five years of age and older had less than a sixth-grade education and were, for all practical purposes, illiterate. ${ }^{4}$ Although shocking, those conditions had long been a part of everyday life in the state. Since the turn of the century, North Carolina's political and business leaders had underfunded human capital development for vast sectors of the population. Public policies such as segregation, disenfranchisement, anti-unionism, and miserly expenditures on public education effectively maintained a racially divided and low-wage labor force. By the early 1960s, however, poverty was moving from the shadow of neglect to the forefront of public policy agendas. The civil rights movement, now at high tide, was challenging the nation to fulfill its promise of equality and opportunity. Not since the Civil War and Reconstruction had so many citizens demanded so clearly the full implementation of equal rights before the law. At the same time, technological innovation was revolutionizing both the agricultural and manufacturing sectors of North Carolina's economy. Automation in the textile and tobacco industries and the mechanization of

4. See Memorandum from Billy Barnes to George Esser, Series No. 8.2 NORTH CAROLINA FUnd PAPERS (on file with the Southern Historical Collection, University of North Carolina at Chapel Hill Library) [hereinafter NCF Papers]. (The documents in the NCF Papers were unavailable to staff editors for cite-checking because they could not be retrieved from an archive.) An overview of the North Carolina Fund and its work is provided in EMILY HERRING WILSON, FOR THE PEOPLE OF North CARolina: The Z. SMith REYNOLds Foundation AT HALF-CENTURY, 1936-1986, at 65-82 (1986). For a useful description of the Fund's early years, see Terry Sanford, Poverty's Challenge to the States, in Anti-Poverty Programs 77-89 (R.O. Everett ed., 1966). See also George H. Esser, Jr., The Role of a State-Wide Foundation in the War on Poverty, in ANTI-POVERTY PROGRAMS, supra, at 90-113. 
agriculture meant that employers' profits no longer depended so heavily on access to a large pool of unskilled labor. Displaced by these processes, thousands of men and women lacked steady employment, and many were migrating out of the state. North Carolina had a net out-migration of more than 250,000 people between 1940 and 1950. In the decade 1950-60, that number fell to 30,000 , but veiled by that seemingly good news was the fact that North Carolina and the rest of the South continued to lose from six to ten percent of young adults between the ages of twenty and thirty-five. ${ }^{5}$

In this context of upheaval and dislocation, Governor Sanford and others in the liberal wing of North Carolina's Democratic Party sought to "awaken" the state to the human and social costs of poverty and racial inequality. ${ }^{6}$ The governor devoted his administration to diversifying the economy, improving public education, and reducing North Carolina's dependence on low-wage manufacturing. He and his supporters also signaled a willingness-indeed, an eagerness - to surrender segregation, so long as they could simultaneously control the pace and direction of change. For progressive Democrats, poverty and racial discrimination became pressing concerns both because of the suffering they inflicted and because they threatened to block the path of the state's economic growth. Writing for a national audience in Look magazine in 1964, Governor Sanford explained:

The President's Council of Economic Advisers estimates that racial bias deprives the U.S. of between $\$ 13$ and $\$ 17$ billion a year in increases in gross national product. In North Carolina, we know that we are 42 nd on the list of states in per capita income because Negroes don't have adequate economic opportunities. If their income equaled that of white citizens, North Carolina would jump to 32nd, at least.

The South badly needs new industry. But what manufacturers would expect to find a worthwhile market in an area where a large percentage of the population is on relief and likely to remain so? What space industry, which must compete mightily for physicists and engineers, would locate in a community ridden with hate and prejudice? The answer to these questions is already being given. In the last several years, new industry has with few exceptions gone most heavily into those Southern states making

5. For background on the political economy of North Carolina, see PETE DANIEL, STANDING AT THE CRossroads: Southern LifE Since 1900 (Eric Foner ed., 1986); PAul LuebKe, TAR HeEl Politics: Myths AND REAlities (1990); Phillip J. WOOD, SOUTHERn CAPITAlism: The POlitical ECONOMY OF NORTH CAROLINA, 1880-1980 (1986); GAVIN Wright, Old SOUTH, NeW South: Revolutions IN THE SOUTHERn ECONOMY Since THE CIVIL WAR (1986). On outmigration, see C. Horace Hamilton, Net Migration to and From North Carolina and North Carolina Counties from 1940 to 1950 (Sept. 1953) (on file with the North Carolina Collection, University of North Carolina at Chapel Hill Library). See also Esser, supra note 4, at 95; C. Horace Hamilton, The USA South: Its Changing Population Characteristics 8, 75-76 (Dec. 1970) (on file with the North Carolina Collection, University of North Carolina at Chapel Hill Library).

6. This "awakening" is, in and of itself, fascinating. It suggests, in part, the effects of the cultural and political amnesia created by the 1950s. Southern liberals of the 1930s and 1940s often possessed incisive understandings of poverty and offered sophisticated prescriptions for change. Nevertheless, the students and liberals of the 1960s had to discover poverty all over again, and they did so within a Cold War and culture-of-poverty framework that was much less useful than the class framework of earlier generations. See generally JOHn Egerton, Speak Now Against the DAY: The GENERATION BEFORE THE CIVIL RIGHTS MOVEMENT IN THE SOUTH (1994); MiCHAEL B. KATZ, IN THE SHADOW OF THE POORHOUSE: A SOCIAL History OF WELFARE IN AMERICA 217-54 (1986). 
the most progress in civil rights. ${ }^{7}$

Poverty, Governor Sanford was quick to add, also exacted a terrible human price:

We can measure the costs of lost productivity, of lost purchasing power, and of the relief rolls. But how do we measure the cost of a crushed spirit or a dead dream or a long-forgotten hope? What is the incalculable cost to us as a people when the children of poverty become the parents of poverty and begin the cycle anew?

The challenge posed by these observations was obvious, but daunting:

How can we in North Carolina reverse trends, motivate people, re-orient attitudes, supply the education and the public services and the jobs that will give all our people the chance to become productive, more self-reliant, and able to compete in the complex but dynamic, exciting but perilous world of today and tomorrow?"

Changing times required innovative strategies for uplifting the state's economically disabled citizens. To that end, the governor and a well-connected coalition of business and educational leaders established the North Carolina Fund in the summer of 1963 . They chartered the new agency as a private, nonprofit corporation whose purpose was to "enable the poor to become productive, self-reliant citizens, and to foster institutional, political, economic, and social change designed to bring about a functioning, democratic society." Governor Sanford chaired the Fund and recruited an interracial board of directors that represented all geographic sectors of the state. Daily operations were overseen by Executive Director George Esser, a law and government professor at the University of North Carolina at Chapel Hill, and a small staff of social workers, ministers, journalists, and academics. For its time, that staff was remarkably diverse. At its peak, it included roughly seventy-five employees, at least half of whom were either women or African Americans. ${ }^{11}$

From 1963 to 1968, the Fund drew the bulk of its financial support from the Ford Foundation ( $\$ 7$ million), which was actively investing in similar projects of social reform elsewhere in urban America and throughout the post-colonial Third World; two local philanthropies, the Z. Smith Reynolds Foundation $(\$ 1,625,000)$ and the Mary Reynolds Babcock Foundation $(\$ 875,000)$, both of which were tied to influential banking and tobacco interests and had records of generous contributions to health and welfare reform; and agencies of the federal government $(\$ 7,042,753)$, including the Office of Economic Opportunity and the Departments of Labor, Housing and Urban Development, and Health,

7. Terry Sanford, The Case for the New South, LoOK, Dec. 15, 1964, at 83-84.

8. Sanford, supra note 4, at 78 .

9. Esser, supra note 4, at 96. See generally SOUTHERN BUSINESSMEN AND DESEGREGATION (Elizabeth Jacoway \& David R. Colburn eds., 1982) (discussing the relationship between white business leaders and the Civil Rights Movement).

10. Three Years of Change: Narrative History of the North Carolina Fund A-3, Series No. 1.1.1, NCF Papers, supra note 4.

11. See WILSON, supra note 4, at 73; Esser, supra note 4, at 90-96; Sanford, supra note 4, at 81-83; N.C. Fund Yields Legacy of Progress, PHILANTHROPY J., May 1994, at 1. For more information on the Fund's board members and their backgrounds, see TERRY SANFORD, BUT WHAT ABOUT THE PEOPLE? 128 (1966). 
Education, and Welfare. That five-year budget of 16.5 million dollars roughly equaled the state of North Carolina's average annual expenditure for public welfare during the mid-1960s. ${ }^{12}$

The North Carolina Fund was the only statewide antipoverty agency of its kind and, as such, played a notable role in shaping the Great Society initiatives that became the hallmark of President Lyndon Johnson's Administration. Both Governor Sanford and Executive Director Esser helped draft the Economic Opportunity Act of 1964, which launched a national assault on poverty, and a number of Fund initiatives served as models for the national effort. ${ }^{13}$ Beginning in 1965, for example, the Fund helped launch the Volunteers in Service to America ("VISTA") program by training participants from all across the country. ${ }^{14}$ Because the Fund's statewide assault on poverty began six to nine months before the national campaign, there was considerable interaction between Fund staff and White House aides, and over the next few years, programmatic ideas were regularly passed back and forth between the Fund headquarters in Durham and the Office of Economic Opportunity in Washington, D.C. ${ }^{15}$

Despite this involvement, Governor Sanford helped pioneer the Great Society from a position of relative weakness. By 1963, he had already begun to run afoul of small-town and rural elites who opposed his economic plans and objected to his moderate stance on civil rights. Those men and women depended on existing social arrangements to guarantee their access to cheap labor and to maintain their status and cultural authority. In fact, they would rise up in 1964 to repudiate Governor Sanford by handing his hand-picked successor a bruising defeat in the Democratic primary. ${ }^{16}$ Sensitive to that impending backlash, Governor Sanford conceived of the North Carolina Fund as a means of keeping his reform agenda alive. As a private corporation, the Fund did its work with foundation and federal grants rather than state appropriations, and, for that reason, it had a unique capacity to bypass hostile conservative lawmakers. ${ }^{17}$ Its purpose, as George Esser explained, was "to

12. For a detailed breakdown of contributions to the Fund, see Emily Berry, "One Building Block in the Battle": The North Carolina Fund and the Legacy of Idealism 5 (1996) (unpublished honors thesis, University of North Carolina at Chapel Hill) (on file with the North Carolina Collection, University of North Carolina at Chapel Hill Library). See also Records of the North Carolina Fund Inventory 19-20, NCF Papers, supra note 4. For North Carolina expenditures on public welfare, see 1 THE BudGeT, 1965-67, at 218-21 (Nov. 6, 1964); 1 THE BudGET, 1967-69, at 174-76 (Nov. 22, 1968); 1 The Budget, 1969-71, at 194-97 (Nov. 23, 1966). See generally Alice O'Connor, Community Action, Urban Reform, and the Fight Against Poverty: The Ford Foundation's Gray Areas Program, 22 J. URB. HIST. 586 (1996) (discussing the role of the Ford Foundation in urban anti-poverty efforts).

13. See Sanford, supra note 4 , at 82 .

14. See Esser, supra note 4, at 108.

15. Three Years of Change: Narrative History of the North Carolina Fund, supra note 10, at A-1. The relationship between the Fund and the Office of Economic Opportunity is documented in the extensive correspondence files in Series 1 of the NCF Papers.

16. See LUEBKE, supra note 5, at 158-59.

17. A close account of the 1964 Democratic primary can be found in JAMES R. SPENCE, THE MAKING OF A GOVERnOR: THE MOORE-PREYER-LAKE PRIMARIES OF 1964 (1968). For the only biography of Sanford, see Howard E. COVIngton, JR. \& MARIOn A. Ellis, Terry SANFORD: 
create the possible" by cultivating like-minded reformers on the local level and nurturing experimentation in antipoverty work. ${ }^{18}$ In that way, the Fund foreshadowed the proliferation of nonprofit social service providers, both in the United States and around the world, that today stand alongside government and business as a vital third sector in the development of social and economic policy. $^{19}$

One of the Fund's first, and in some ways definitive, undertakings was its Volunteers program, which, for two consecutive summers, brought a select group of college students face to face with the realities of poverty. The Volunteers explained their motives for service in lengthy letters of application, and they recorded their experiences, doubts, and discoveries in detailed daily logs. We have worked extensively in those materials and have supplemented them with three dozen oral history interviews and a survey of almost 100 Fund veterans. Together, those sources highlight the vital role student activists played in shaping both the Fund's work and the general character of the 1960s; they demonstrate the capacity of volunteerism to influence the trajectory of individual lives; and, most important, they reveal the War on Poverty's potential for expanding the boundaries of participatory democracy. In ways that none of the participants fully anticipated, the Fund offered its Volunteers not simply a summer of service but also an opportunity to rethink the meaning of citizenship for both themselves and the people they set out to help. ${ }^{20}$

III

\section{THE VOLUNTEERS PROGRAM}

The North Carolina Volunteers had its genesis in a tutorial program for underprivileged children that Terry Sanford had tried unsuccessfully to persuade the state legislature to support. Inspired by the Peace Corps, the Governor was convinced that the program would deliver needed services while also cultivating a new generation of enlightened state leaders. When his request was denied, Sanford and Fund officials turned to the U.S. Office of Education, which provided $\$ 50,000$ from monies set aside to experiment with the idea of establishing a national service corps. With that grant and $\$ 50,000$ from its own resources, the Fund launched its Volunteers program under the direction of Jim

Politics, Progress, And Outrageous Ambitions (1999). On the creation of the Fund and the political logic of its establishment as a private, nonprofit corporation, see Three Years of Change: Narrative History of the North Carolina Fund, supra note 10, at A-1. See also SANFORD, supra note 11, at $125-29$.

18. Esser, supra note 4, at 92.

19. See generally PETER F. DRUCKer, MANAging THE NON-Profit Organization: PRACTICES AND PRINCIPLES (1990).

20. The Volunteers' essays and logs, along with our interviews, are on deposit in the Southern Historical Collection, University of North Carolina at Chapel Hill Library. For comparative purposes, the best work to take up similar issues of volunteerism and social action is DOUG MCADAM, FREEDOM SUMMER (1988). The program that most resembled the North Carolina Volunteers was Volunteers in Service to America, which was modeled, in part, on the North Carolina experiment. The North Carolina Fund's relationship with VISTA is detailed in Series No. 3.4, NCF PAPERS, supra note 4. 
Beatty, a national collegiate track star from the University of North Carolina at Chapel Hill. ${ }^{21}$

In March 1964, Beatty and his co-workers blitzed the state with a call for volunteers for the first summer program. Within a matter a weeks, they were inundated with more than 500 applications. Teams of interviewers then selected 100 finalists who represented every college campus in the state-small and large, public and private, black and white. Most of the "First One Hundred," as they were dubbed by the state's press and the Fund's publicity office, came from middle-class households-economically secure, but not particularly prosperous. Women outnumbered men three to one, reflecting both the gendered character of social service and the fact that Fund recruiters targeted college majors that tended to enroll large numbers of women: education, psychology, sociology, and English. Racial representation in the group roughly reflected the general population. The presence of fifteen African-American students flaunted the practices of segregation and signaled the Fund's determination to confront the role of racial discrimination in the perpetuation of poverty. The challenge for those chosen to be Volunteers was not simply to serve the poor, but also to model for themselves and their society an inclusive notion of public life that otherwise had little currency in the segregated South. ${ }^{22}$

Members of the First One Hundred, and the more than 250 students who followed them in 1965, gave a variety of reasons for answering the call to service. In their applications, many of the white students spoke of their religious faith and their desire to practice the principles of Christian brotherhood by venturing across the boundaries of class and race. A junior from Catawba College believed it was his "duty to help those who are oppressed by poverty and ignorance. I don't mean to sound pious, but this is the way I think the Christian can ... fulfill the work of Christ in today's world." ${ }^{23}$ A young woman echoed those sentiments and suggested how they might undercut a lifetime of racial indoctrination: "Here in the South, most of us have been taught to think poorly of the Negro. When I look into the eyes of a white child I see no great difference. I see a human being in both." ${ }^{24}$ Those sentiments convinced her that the time had come "to do something about the

21. See David Andrew Biggs, The First One Hundred 30 (1992) (unpublished honors thesis, University of North Carolina at Chapel Hill) (on file with the North Carolina Collection, University of North Carolina at Chapel Hill Library); Three Years of Change, supra note 10, at A-15. In 1965, the Fund supported the Volunteers program with \$274,316 from the Office of Economic Opportunity and $\$ 32,444$ of its own resources. See Three Years of Change, supra note 10, at A-15.

22. For a detailed account of the recruiting process in 1964 and a demographic profile of both summers' volunteers, see Berry, supra note 12. On the Fund's determination to challenge established forms of volunteerism, see Sanford, supra note 4, at 81. See generally Doug McAdam, Gender as a Mediator of the Activist Experience: The Case of Freedom Summer, 97 AM. J. OF SoC. 1211 (1992). On the Volunteers' nickname, see Videotape: The First One Hundred, NCF Papers, supra note 4.

23. Application Essay, Series No. 2.1.3, NCF Papers, supra note 4.

24. Id. 
problem of the underprivileged people instead of just thinking about them." 25 Similar concerns pervaded the application essays of African-American students, although their writings were shaped in distinctive ways by a firsthand knowledge of poverty and discrimination. A sophomore from the historically black Elizabeth City State College wrote, "I was reared in poverty, and to a large extent still live in it. I know what it is to be among the have-nots and to be faced with the foreknowledge of defeat and rejection."26 For this young man and other black Volunteers, the Fund's work tapped into a tradition of racial self-help and dovetailed with civil rights activism. ${ }^{27}$

These motivations came together in unique combinations for each individual, but the one theme that resounded in nearly all of the students' writings was a conception of citizenship defined by the militarized culture of the Cold War and President John F. Kennedy's call for patriotic self-sacrifice. In a nation threatened by communism abroad and social strife at home, the Volunteers felt a duty to what they saw as American ideals. "Because I am a concerned American, I think to be able to help others is more than an opportunity; it is a duty that is part of the democratic form of government which we have," wrote Hugh Jones (pseudonym). ${ }^{28}$ Battling poverty became a way of advancing the cause of social progress, achieving justice at home, and thus strengthening the nation for the global confrontation with communism. Guided by those principles, the student Volunteers dubbed themselves "Citizen Soldier[s]"29 in what President Lyndon Johnson had only months before described in his State of the Union address as a national "War on Poverty."

In the summers of 1964 and 1965, the Volunteers gathered in early June for a week of training at Duke University. Visiting speakers-sociologists, lawmakers, and administrators from various social service agencies-said little about jobs, wages, and affordable housing. Instead, they kept a tight focus on the "culture of poverty" and the ways it worked to "twist and deform" the human spirit. ${ }^{31}$ As Sharon Young (pseudonym) wrote shortly after her orientation, "[l]ecturers and discussants constantly referred to 'these people.' I was told that they were a people who needed to be given a sense of dignity and pride which was absent from their lives.... We, the Volunteers, were ... to provide the atmosphere that could foster ambition, dissatisfaction, and ultimate

25. $I d$.

26. $I d$.

27. $I d$.

28. Id. The records of the North Carolina Fund are open to researchers with one important restriction. To protect the privacy of the volunteers, the Southern Historical Collection has requested that pseudonyms be substituted for individual names in published references to application essays and daily logs.

29. Interview with Johnette Ingold Fields (October 18, 1995) (on file with the Southern Oral History Program Collection, Southern Historical Collection, University of North Carolina at Chapel Hill Library) [hereinafter Fields Interview].

30. See Walter I. Trattner, From Poor law to Welfare State: A History of Social WELFARE IN AMERICA 322 (1999).

31. See Michael Harrington, The Other America: Poverty in the United States 2 (1964). 
change." ${ }^{32}$ After three days of such preparation, Young and her fellow students climbed into buses and cars and made their way to host communities chosen to represent the regional and demographic diversity of the state.

Once in the field, the Volunteers performed a variety of tasks. A majority spent their summer of service working with children in educational and recreational programs. In many cases, these interactions in the classroom or on the playground led the Volunteers into the homes and neighborhoods of their young charges, where they became immersed in the lives of individual families. They tutored adults as well as children, counseled high school drop-outs, served as advocates for access to health care and better housing, and, in the process, became increasingly aware of the complex causes of poverty. Other students took temporary positions in county health departments, where they worked with public health nurses to conduct dietary surveys, assisted in clinics, renovated homes, installed sanitary privies, and helped develop community water systems. In rural mountain communities, Volunteers drove the bookmobiles that provided residents with their only access to public libraries and established local craft cooperatives to provide employment and supplement family incomes. As remuneration for these activities, the Volunteers received $\$ 250$ plus room and board for a ten-week program. ${ }^{33}$

Almost immediately, the Volunteers encountered scenes so abject as to challenge comprehension. One young woman was stunned by the squalor and deprivation she witnessed in a shack not far from the campus of the University of North Carolina at Chapel Hill. She reported the conditions in her daily log:

Only five of the children were home. We read to them and played with them. Those children do not know how to even look at a book-Sophia, who is 6 [and] starts to school next year, picked up a book upside down and turned the pages from back to front.... The place has a sickening smell-The children have sores and whelps from beatings all over them-They also have protruding stomachs. ${ }^{34}$

When faced with such suffering, most of the Volunteers turned, at least initially, to explanations that were both familiar and comforting. While they never quite blamed the poor for their plight, they did locate the causes of poverty within a cluster of social and psychological inadequacies. The poor, it seemed, "believed in nothing and [had] little faith in their own capacities." ${ }^{35}$ Such views provided both emotional distance from hardship and assurance that the Volunteers could "fix" the people they encountered. "All we had to do was clean up this one generation," a former Volunteer recalled many years later, "educate these people and lift them up, and it would be over with. We really believed that." ${ }^{6}$

A significant minority of the Volunteers never escaped this way of thinking.

32. Daily Log, Series No. 2.1.2 (Aug, 18, 1964), NCF Papers, supra note 4.

33. See Billy E. Barnes, The North Carolina Fund: A Progress Report, 30 Popular Gov'T, June 1964, at 1-5, 22; see also Description of Tasks Performed by the North Carolina Volunteers, Summer 1964, Series No. 2.1.2, NCF Papers, supra note 4.

34. Daily Log, Series No. 2.1.3 (Aug. 4, 1965), NCF Papers, supra note 4.

35. Berry, supra note 12 , at 50 .

36. See Fields Interview, supra note 29; see also Application Essay, Series No. 2.1.3, NCF Papers, supra note 4. 
For most, however, face-to-face encounters made it increasingly difficult to typecast the people they had come to serve. With few exceptions, the Volunteers knew little of the realities of poor people's lives. What they thought they understood came primarily from newspaper accounts, popular stereotypes, and scholarly abstractions. Over the course of ten weeks in the field, students wrestled with the tension between those "previously-held opinions and recently-gained impressions." ${ }^{37}$ One of the most striking features of their daily logs is how characterizations of the poor move grammatically from the third to the first person. As poverty came to have a human face, its afflictions could no longer be ascribed simply to "those people." They were instead the troubles of Pete, a teenager whose anger got him into fights and often landed him in jail, or the struggles of families like the Townsends, known by social workers as the "worst case" in their county, but in fact desperate for their children to have an education and the chance of a better life. ${ }^{38}$

Through personal encounters, the Volunteers moved, often haltingly, toward thinking about themselves and the poor in ways that were both new and emancipating. Anne Henderson (pseudonym), a sophomore from the exclusive Saint Mary's Junior College in Raleigh, found it difficult to "explain to... friends and classmates ... that there is so much more to life than the narrow, sterile, prejudiced world that they know and accept." ${ }^{, 39}$ After two months in the North Carolina mountains, she wanted "more than ever ... to take some real action." An Another student who had served in 1964 and who re-applied in 1965 reported that involvement with the North Carolina Fund had marked a turning point in her life. In her 1965 application, she wrote, "The program was one of the most worthwhile things that has ever happened to me. . . It forced me to look at myself, while I was helping others to look at themselves." ${ }^{41}$ Carol Kendall (pseudonym) shared that assessment. She described her summer as "the richest and most rewarding" experience of her life. "I find that many of my attitudes about poverty and people in poverty have been drastically changed." ${ }^{42}$ Cindy Johnson (pseudonym), a white Volunteer from Stedman, a small town in eastern North Carolina, provided the following assessment: "The experiences of this summer-working, living and playing with fellow Negroes has been invaluable-has begun, I feel, to break a cycle of my own poverty." ${ }^{43}$ While the trajectory of these transformations seems clear, their depth is less easily plumbed. Nevertheless, both contemporary and retrospective evidence leaves no doubt that many of the Volunteers found themselves caught up in experiences with a potential to shift their loyalties away from the world of their

37. Daily Log, Series No. 2.1.1 (June 14-17, 1964), NCF Papers, supra note 4.

38. See Daily Log, Series No. 2.1.1 (July 24, 1964), NCF Papers, supra note 4; Id. No. 2.1.2 (June 30, July 30, and Aug. 11, 1964).

39. Application Essay, Series No. 2.1.3, NCF Papers, supra note 4.

40. Id. (upon application for a second summer).

41. Id.

42. $I d$.

43. Daily Log, Series No. 2.1.1 (July 12, 1964), NCF Papers, supra note 4. 
parents' generation and its established principles of power and privilege. ${ }^{44}$

The Volunteers program was especially effective in exposing the limitations of white students' self-satisfied racial liberalism. Most of the white Volunteers emphasized in their application essays both their capacity to work with any ethnic group and their commitment to interracialism. Putting those principles into practice, however, was often harder than the students had imagined. After all, they came from schools and communities that had undertaken only the most limited forms of desegregation. In 1965-66, the percentage of black students who attended almost exclusively black elementary public schools (with ninetynine to one hundred percent black enrollment) in three of the state's largest urban districts were $97 \%$ in Charlotte, $98.5 \%$ in Raleigh, and $88.7 \%$ in Winston-Salem. ${ }^{45}$ The Volunteers' summer experiences forced them to confront the oppressive power of racism-both their own and that which permeated the society at large. For many Volunteers, the test came in the intimate act of sharing a meal with black teammates or with members of a black community. Such associations violated one of the South's most deep-seated taboos. A sophomore from a small, church-run college strained against the grip of southern customs on her first day in the field. "Tonight we ate supper in a Negro school," she wrote in her daily $\log$. " "I felt a little nauseated, mainly because I had never before eaten in a Negro school, and I was becoming sick." ${ }^{47}$ That reaction so disturbed the young woman that she resolved to make the examination of her racial phobias one of her chief projects. "By the end of the summer, I should feel completely different." ${ }^{\prime 8}$

Because the Volunteers lived and worked in integrated teams, race posed a constant challenge. White students found few escapes from the contradictions of their racial views. One white Volunteer was infuriated when he and his teammates were "served poorly, ordered around, talked about, [and] called names" in a segregated restaurant. ${ }^{49}$ "Personally, I think that someone ought to bomb the place," he confided in his daily $\log .{ }^{50}$ A few weeks later, however, the same young man reacted with only slightly less anger when a white female coworker became too friendly with young black men in the neighborhood to which they were assigned. Such inconsistencies frustrated African-American Volunteers. In weekly group meetings, Charlotte Williams (pseudonym) demanded to know why, whenever the team moved into new quarters, she was

44. For a discussion of a similar learning process among student volunteers in eastern Kentucky, see Thomas J. Kiffmeyer, From Self-Help to Sedition: The Appalachian Volunteers in Eastern Kentucky, 1964-1970, 64 J. S. HIST. 65 (1998).

45. See United States Commission on Civil Rights, 1 Racial Isolation Within Public SCHOOLS 4 (1965).

46. Daily Log, Series No. 2.1.1 (June 22, 1964), NCF Papers, supra note 4.

47. $I d$.

48. Id. On the pace of desegregation in North Carolina, see WILliAm H. CHAFE, CIVILITIES AND Civil Rights: GREENSBORO, NORTH CAROLINA, AND THE BlACK STRUGGLE FOR FREEDOM 10506 (1980).

49. Daily Log, Series No. 2.1.1 (June 25, 1964), NCF Papers, supra note 4.

50. Id. (July 14, 1964). 
the last to get a roommate; she chastised white Volunteers for describing the diet of poor families as "typical Negro food"; and she insisted that her teammates learn to pronounce "the word "Negro"" and abandon the polite disrespect of "Nigra."

Such confrontations demonstrated that habituated ways of thinking and behaving were not easily changed. Indeed, the white Volunteers' best intentions were often caught short. A young woman who worked as a teacher's aid in an all-black elementary school titled an entry in her log, "My most embarrassing moment as a Volunteer (I forgot my children were Negro)":

Last week I went downtown and bought paint for puppets' faces, and paint for a puppet stage, and yarn to use for puppets' hair. My selections were good, I thought. This morning I went to the room and asked each child to get his puppet. Then I showed them how to put on the hair-paint the face and features. One of the children said, “... where is the brown paint?" You see I had purchased "flesh colored paint" and yellow hair, and black and brown hair-and the children wanted to make puppets like themselves. I almost died. I said very quickly, "Children since we are pushed for time we will not paint your puppets' skin today. We will just try to get their hair on." (I'm making a[nother] trip downtown before Monday. $)^{52}$

In a similar situation, a group of white Volunteers who worked with a black preschool teacher were at a loss to understand the woman's coolness. One Volunteer wrote that "Mrs. Brown keeps herself very removed from us: She's the boss." ${ }^{53}$ The relationship became so strained that the Volunteers mentioned the problem to the local school superintendent, who surprised them by suggesting that they had given offense in ways they never understood. "He thought the reason for our cool relationship ... was due to the fact that we were white... [and the teacher] wanted to show she was perfectly competent and didn't need our help." ${ }^{54}$ In such circumstances, the Volunteers had to confront the paternalism that too often characterized their own labors. They learned slowly-and sometimes painfully-the limitations of patron-client relations. Effective reform required instead that the Volunteers engage their hosts as equals, acknowledging the fullness of their claims to citizenship and their capacity for independent action. ${ }^{55}$

As the students began to translate that lesson into practice, they found themselves ensnared by the tangle of connections that tied racism and poverty to political power, class interests, and the privileges of whiteness. The Volunteers experienced some of the stiffest resistance and indifference from where they expected it the least. Poor whites were often deeply suspicious of the Fund and its activities. They had much to gain from the antipoverty program, but, in their estimation, even more to lose from the prospect of racial leveling. In one white community after another, Volunteers found themselves

51. Id. No. 2.1.2 (June 25 and July 1, 1964).

52. Id. No. 2.1.3 (July 30, 1965).

53. Id. No. 2.1.1 (July 24, 1964).

54. Id. (Aug. 26, 1964).

55. See id. No. 2.1.3 (July 30, 1965), No. 2.1.1 (July 24 and Aug. 26, 1964). 
rejected as "communists," "freedom fighters," and "civil rights workers." Except in the mountains, where the black population was small and therefore perceived as less threatening than elsewhere in the state, the North Carolina Fund won only limited acceptance in poor white communities.

That rejection of the Fund was reinforced by middle-class businesses and political leaders, who were equally resistant to lowering the walls of segregation or surrendering the class prerogatives that racial discrimination helped to sustain. Local officials invited the Volunteers into their communities both to secure needed services and to take advantage of the North Carolina Fund's ties to the federal Office of Economic Opportunity. Beginning in 1964, the Fund became a major pipeline for new federal investments in community development and job creation. Yet, even as they sought to benefit from that largesse, local leaders often defended established lines of authority, power, and privilege. $^{57}$ Sue Hester (pseudonym) reported from the small eastern town of Laurinburg that

not one white person has gone out of his way to make us welcome... This very obvious "snubbing" is beginning to tell on group morale. . . People here seem to be trying desperately to ignore the fact that we are here, as ostriches with their heads in the sands of their own prejudice. It's as if we're the symptoms of some dread disease they don't want to know they have.

Torn between outrage and her own middle-class manners, Hester exclaimed, "It makes me so mad at these self-satisfied, self-righteous whites that I could kick them in the wazoo!" 59

Local leaders also worried about the potential of the Fund's work to catalyze and legitimate organizing initiatives within poor neighborhoods. Marc White (pseudonym) belonged to a team of Volunteers assigned to work with the Parks and Recreation Department in Durham, a tobacco manufacturing town with a large black community and one in which white politicians and some members of the black middle class shared an interest in limiting independent political activity among poor residents. At first, White felt excited by the promise of the job. After an introductory meeting with Durham civic leaders, he reported in his daily log that "the upper levels of the Durham bureaucracy are vitally concerned with the problems we have been sent to help out with." However, the limits of that concern soon became apparent. White and his teammates grew weary of keeping order on ball fields and began organizing parents to build a playground in a poor black neighborhood where the city refused to provide recreational services. ${ }^{61}$ That affront prompted a tonguelashing from the mayor:

The mayor launched a politely-phrased tirade. To wit, we, the volunteers, must

56. See id. No. 2.1.3 (Aug. 16, 1965), No. 2.1.2 (July 27, 1964).

57. See Esser, supra note 4, at 105.

58. Daily Log, Series No. 2.1.2 (Aug. 4, 1964), NCF Papers, supra note 4.

59. Id.

60. Id. (June 22, 1964).

61. See id. 
remember that we were employees (in effect) of the City of Durham, and under the city's thumb. We are here to serve as requested, not to change the requests. In short, we are here to be un-creative, and not to fight poverty, but to play the city's conservative ball game. ${ }^{62}$

In a small farming community south of Durham, town officials took an even more direct approach. They had initially requested assistance from the Volunteers in reopening the public library, but were horrified by the way that the young people interpreted their task. "We went in and cleaned and dusted and cleaned some more," recalled Adisa Douglas, who had been one of the first black students to enroll at the University of North Carolina at Chapel Hill. ${ }^{63}$ Her interracial team "re-established some order to the books and opened a children's section [with] a reading corner." ${ }^{94}$ They then visited "both [b]lack and [w] hite neighborhoods" to announce the library's re-opening. ${ }^{65}$ "Children came in droves, and these were primarily black children. White residents of the town went up in arms. Black children did not use the public library! We were threatened by the Klan and had to withdraw from the town altogether." ${ }^{966}$

When faced with such hostility, teams across the state adopted a common strategy: They hunkered down in black communities where they were welcomed and felt that they could make a meaningful contribution. As several Volunteers explained, they took it upon themselves to set "the pace for integration" and to model for others a vision of what "could be." ${ }^{67}$ They had become, in their own estimation, "charter members of an idea." Marc White defied the mayor and continued organizing the black community so that his playground would survive his departure and so that neighbors could structure their own recreational programs. In other communities, Volunteers took up similar efforts. One team set up a mothers club for poor women, so that "they [might] investigate for playgrounds" poor coastal community secure federal dollars for an after-school tutoring and recreational program that local officials refused to fund; and, in yet another community, a group of Volunteers worked with poor parents to turn a summer

62. Id. (June 28, 1964).

63. Adisa Douglas, North Carolina Volunteers' Survey 4 (unpublished survey, on file with authors).

64. Id.

65. $I d$.

66. Id. Volunteers working in the Harnett County town of Coats reported a similar incidence of a library closing after Volunteers brought in black children. Here, too, Volunteers were forced to abandon their work after threats from the Klan. See Daily Log, Series No. 2.1.3 (June 28 and July 1, 1965), NCF Papers, supra note 4. That same summer, the Fund withdrew its Volunteers from Craven County when nightriders fired shots into the house where the students were living. See id. (July 10, 1965); Advisory Committee Meeting Notes, Series No. 2.1.3 (July 12, 1965), NCF Papers, supra note 4; Oliver Williams, Rebirth of Klan Counters Moderate Action in State, RALEIGH NEWS \& OBSERVER, Aug. 23, 1964, at 1; Big Gains Scored by Carolina Klan, N.Y. TIMES, Sept. 6, 1964, at 34 (discussing the increase of Klan activity in North Carolina during this period).

67. Douglas, supra note 63, at 5.

68. Daily Log, Series No. 2.1.1 (July 26, 1964), NCF Papers, supra note 4.

69. Id. No. 2.1.2 (June 30, 1964). 
playschool into a Head Start program. ${ }^{70}$ Such organizing efforts could go only so far in the course of ten weeks of summer work, but they reflected nonetheless a fundamental change in the students' understanding of citizenship. The Volunteers had come to embrace activism no less than service as an essential element of democracy. The poor, they began to argue, had not only a responsibility to live as productive, self-reliant citizens, but also a right to demand, in return, political rights, higher wages, improved housing, and better schools.

The Volunteers' expanded sense of rights and obligations-both their own and those of the poor-helped steer the North Carolina Fund in dramatically new directions. At the end of their summer of service, many of the students complained bitterly about the ephemeral nature of their work. What good was it to tutor a child or to provide organized recreation, they asked, if those programs would disappear as soon as the summer ended? Others went even further and openly mocked the idea that poverty might be eradicated by rehabilitating the poor rather than addressing issues of politics and economics. "Taught one 7 year-old boy to tie his shoes," a Volunteer quipped in her log. ${ }^{71}$ "Very important for breaking the cycle of poverty: if we're to help them lift themselves by their shoe straps, it helps if their shoes stay on."

Those challenges resonated with new voices rising up from within poor communities themselves. In many places where the Volunteers worked, the summer program provided a public stage for indigenous leaders who had their own ideas about how best to fight poverty. In Durham, for instance, the men and women who had worked with Marc White to build a playground moved next to organize a rent strike and to picket City Hall. They insisted that the streets in their neighborhood be paved, that garbage be collected more regularly, and that housing laws be enforced against white realtors and slum lords. ${ }^{73}$ Such demands from below worked, in turn, to amplify incentives from above, as the Office of Economic Opportunity coupled federal dollars ever more tightly to the goal of ensuring the "maximum feasible participation" of poor people in the framing and implementation of antipoverty initiatives. ${ }^{74} \mathrm{By}$ late 1965, Fund officials were ready to shift course. They felt pinched by these

70. See id. No. 2.1.3 (July 26 and Aug. 14, 1965).

71. Id. No. 2.1.1 (July 1, 1964).

72. Id. Another volunteer complained openly of superiors and local officials who "appeared to be self-satisfied with the mere fact of the Fund." Id. (Aug. 19, 1964).

73. See Osha GRAy DAvidson, The Best of EnEMIES: RACE AND REDEMPTION IN THE NeW South 153-85 (1996); Chris Gioia, How to Get Out of Hell by Raising It: Race and Politics in Durham's War on Poverty 32-54 (1996) (unpublished honors thesis, University of North Carolina at Chapel Hill) (on file with the North Carolina Collection, University of North Carolina at Chapel Hill Library).

74. The term "maximum feasible participation" was inserted into the language of the Economic Opportunity Act by White House aides who wanted to make sure that poor people themselves, not just politicians and social welfare professionals, were involved in the design and implementation of antipoverty programs. 42 U.S.C. § 2701, repealed by Pub. L. No. 97-35, 95 Stat. 519 (Aug. 13, 1987). See generally DANiEl P. MOYNIHAN, MAXIMUM FeAsible Misunderstanding: COMMUNiTy ACTION IN THE WAR ON POVERTY (1969) (advancing a critical view of this effort). 
pressures and frustrated by the intransigence that had too often greeted their initial efforts. When the summer program ended in August of that year, the Fund disbanded its Volunteers program.

A number of factors contributed to that decision. First, Fund staff had grown increasingly concerned about the safety of the Volunteers, the majority of whom were white women, as the Civil Rights Movement heated up and violence directed at interracial groups intensified. ${ }^{75}$ Second, and more important, federal underwriting for the Volunteers program had run out by 1965, and Fund leaders had not been able to locate another source of support. To continue the Volunteers program would have required the Fund to draw more heavily on its own resources at precisely the time when many within the organization were raising questions about the efficacy of spending money on middle-class volunteerism instead of developing the capacities of the poor. "It seems to me that the North Carolina Volunteers have done what they intended to do," observed staff member Betty Ward. "That is, they have demonstrated that college students, with their refreshing idealism and enthusiasm, can show us a different way of looking at the poor." " It was now time for something more. Ward and other Fund leaders had come to the same conclusion as many of the student Volunteers: "the real issues ... were issues of power, and ... not a whole lot was going to change ... without changing internal power." ${ }^{77}$ For that reason, the Fund began in late 1965 to direct its attention toward community organizing. It financed independent poor people's movements and began training former Volunteers and the poor themselves as Community Action Technicians who would live and work full-time in the places they served. In eastern North Carolina, for example, the Fund underwrote the People's Program on Poverty, an organization of black sharecroppers, domestic workers, and small farmers, and in Durham, the Fund helped finance United Organizations for Community Improvement, which coordinated rent strikes and led local civil rights protests. The goal in these and other such partnerships was not simply to deliver services, but to give the poor the institutional and financial footing from which to press their demands. ${ }^{78}$

Through this shift in tactics, the Fund unleashed a wave of activism in poor communities across North Carolina. As the poor began to organize, picket, and protest, the Fund's opponents became increasingly shrill in their recriminations. One newspaper in the eastern part of the state insisted that the Fund had steered the War on Poverty off of its intended course. The editor saw "no

75. See Erika LeMay, Battlefield in the Backyard: A Local Study of the War on Poverty 23 (1997) (unpublished master's thesis, University of North Carolina at Chapel Hill) (on file with the North Carolina Collection, University of North Carolina at Chapel Hill Library).

76. Betty Ward, Series No. 2.1.4 (1966), NCF Papers, supra note 4.

77. Interview with Diane Sasson (Oct. 28, 1995) (on file with the Southern Oral History Program Collection, Southern Historical Collection, University of North Carolina at Chapel Hill Library); see also Esser, supra note 4, at 102.

78. See Gioia, supra note 73; Lisa Gayle Hazirjian, The Daily Struggle: Poverty, Power, and Working-Class Life in Rocky Mount, North Carolina, 1929-1969 (unpublished Ph.D. dissertation, Duke University) (in progress); LeMay, supra note 75. 
reason why the anti-poverty program should be controlled by the poor any more than social security should be run by the elderly ... or the draft run by draftees.... Congress never intended that the 'poor' should run the antipoverty war [but only that their views] should be taken into account."79 Another paper accused the Fund of waging "guerrilla warfare," Congress, Representative James Gardner charged that the agency had "redirected the War on Poverty ... into creating a political machine." At risk, in Gardner's view, were deep-seated notions of civic identity in which race and class had long determined access to the fullness of American citizenship. To work with, rather than for, the poor was to acknowledge not only their humanity but their claim to power and privilege as well. For Gardner and his constituents-many of them still reeling from the assault on the racial foundations of their own status - such a simple precept provoked a flood of anger and anxiety. The North Carolina Fund, in their view, promised not so much economic development as social chaos and disorder. ${ }^{82}$

By 1968, the Fund's future was in peril. The agency had expended its initial foundation grants, which had been awarded for a five-year period, and the national War on Poverty was under siege. When the Fund's philanthropic backers offered to extend their support, its leaders declined. In part, they held to a vision of the Fund as a temporary and experimental agency. The founders had no desire to see their work routinized; to allow such a development, they insisted, would be to sacrifice innovation to the very forms of inertia that had for so long crippled the nation's response to its most needy citizens. Even more crucial were considerations of the changing political climate. In North Carolina, as in the country at large, the political alignments that had made the War on Poverty possible were beginning to dissolve. Liberal Democrats were in retreat by 1968 , scrambling to ward off a white backlash against civil rights and to answer charges that they were somehow responsible for the violence and disorder that engulfed many communities across the state and nation in that year. During the spring primaries, a significant minority of North Carolina's white voters rallied behind the presidential candidacy of George Wallace, and in the November elections, Richard Nixon became the first Republican to carry the state since Herbert Hoover in 1928. Like liberals elsewhere in the nation, the Fund's architects saw few options but to settle for what seemed politically viable. They disbanded the Fund and dug in to defend hard-won enhance ments of federal transfer payments-Aid for Families with Dependent Children, food stamps, jobs programs, supplemental security income, and Medicaid-which,

79. PPOP Owes CADA an Apology, HertFord COUNTY Herald, Feb. 20, 1967.

80. The Local Poor Have Their Say, Northampton News, Aug. 4, 1966.

81. Memorandum from Representative James Gardner to George Esser (Nov. 21, 1967), NCF Papers, supra note 4.

82. See id. For more on these matters, see Gioia, supra note 73; Hazirjian, supra note 78; LeMay, supra note 75. On the history of race and class in the definition of American citizenship, see Rogers M. Smith, American Conceptions of Citizenship and National Service, in NEW COMMUNITARIAN THINKING: PERSONS, VIRTUES, INSTITUTIONS, AND COMMUNITIES 237-58 (Amitai Etzioni ed., 1995). 
even though they did little to address the causes of poverty, at least strengthened the safety net for the most vulnerable Americans. ${ }^{83}$

Fund officials did take steps to see that a number of initiatives would be continued. Director George Esser and his staff helped create three new, nonprofit organizations with specific goals: the Foundation for Community Development, which carried forward the work of grassroots organizing among the poor; the Manpower Development Corporation, which focused on job training and rural economic development; and the Low-Income Housing Development Corporation, which promoted the construction of affordable housing. Many people on the Fund staff went to work for one of these organizations, and both the Ford Foundation and the Office of Economic Opportunity continued to provide some support. With the Fund's demise, the anti-poverty effort in North Carolina lost its place at center stage in the state's politics. Indeed, of these three spin-off organizations, only the Manpower Development Corporation survived over the long term. ${ }^{84}$

IV

\section{ANALYSIS OF THE LASTING EFFECTS OF THE NORTH CAROLINA FUND}

The North Carolina Fund, like the War on Poverty, fell victim to racial divisiveness and Americans' continued refusal to come to terms with issues of class in a purportedly classless society. ${ }^{85}$ Yet, while its programs have been long forgotten by most North Carolinians, its legacies survive in the lives of the former Volunteers. Miriam Dorsey, a Raleigh native, served with the First One Hundred and has since built a career around political activism. At the end of her summer of service, she briefly considered joining the Peace Corps, but ventured instead to Washington. She secured a staff position with North Carolina Representative Richardson Preyer and, enticed by a study of wage discrimination in Congress, found her way onto the Capitol Hill Woman's Political Caucus during the early 1970 s. $^{86}$ Dorsey eventually chaired the group and was thoroughly caught up in the women's movement that was taking shape around the country. Her interests brought her back to North Carolina in 1977 to join the administration of Governor James Hunt. She served the governor as

83. On the guiding vision of the North Carolina Fund as a temporary, experimental agency, see Esser, supra note 4; Memorandum from George Esser, Series No. 1.2.6, NCF Papers, supra note 4; Three Years of Change, supra note 10, at A-4. For a general account of the waning of the War on Poverty and 1960s-era reform, see ALLEN J. MATUSOW, THE UNRAVELING OF AMERICA: A HisTORY OF LIBERALISM IN THE 1960s (1984).

84. On the phase-out of the North Carolina Fund, see Memorandum from George Esser, Series No. 1.2.6, NCF Papers, supra note 4; Interview by Patricia Maloney Alt with George Esser, Series No. 5.3 (Jan. 2, 1970), NCF Papers, supra note 4. For information on the continuing work of the Manpower Development Corporation, see MDC-Expanding the Economy, Developing the Workforce (visited Feb. 9, 2000) <http://www.mdcinc.org $>$.

85. See generally Jill QuAdAGno, THE COlOR OF Welfare: How RACISM UNDERMined THE WAR ON POVERTY (1994).

86. Richardson Preyer was the protégé of Terry Sanford who was defeated in the 1964 Democratic gubernatorial primary. He was elected to the U.S. House of Representatives in 1968. 
Executive Director of the North Carolina Council on the Status of Women and as his Senior Policy Development Analyst and Women's Policy Adviser. In the latter capacity, Dorsey authored landmark legislation on domestic violence in 1979 and spearheaded the unsuccessful campaign to have North Carolina's General Assembly ratify the Equal Rights Amendment during the early 1980s. Today, she credits her work as a Volunteer for giving her life a guiding purpose: "Everything I have done since that summer ... has been trying to broaden civil rights for different groups of people. Whether it's race or sex or class, civil rights is the basic thing I have been working for all these years. ${ }^{97}$

Emily Coble, who also served during the summer of 1964, has led a quieter, but no less committed life. After leaving the Fund, she signed on for two tours with the Peace Corps and then returned to North Carolina to begin work as an elementary school teacher. Today, she runs a bilingual classroom for Spanishspeaking children of migrant farm workers. Just as thirty years ago she delighted in working with the impoverished children in a Fund-supported playschool, she now feels a commitment to helping new immigrants make their way in an often hostile and unwelcoming world. A self-described "stranger in a strange land," Coble relies on memories of her summer as a Volunteer to supply her with the ability "to be tolerant, to appreciate, to respect, and to care." 88

In 1996, Emily Coble and other veterans of the North Carolina Fund gathered for a reunion and conference. ${ }^{89} \quad$ Together with more than 200 grassroots activists, policymakers, and representatives of charitable foundations, they discussed and debated the experiences of the past, the lessons of history, and the challenges of our own time. Even in the 1960s, when the economy was growing and national leaders stood committed to equal opportunity, local communities, as much as the federal government, were key battlegrounds for change. Today, in an age of welfare reform and devolution, that is as true as ever. The story of the North Carolina Fund and its student Volunteers, therefore, has much to teach us. ${ }^{90}$

First of all, the story reminds us of the importance of activist citizenship in a diverse democracy. The young people who attended the 1996 conference were intensely concerned about the continuing issues of racial justice and economic equality. Nevertheless, they work in an environment that is constrained in powerful and sometimes contradictory ways by the legacies of the past. Lacking either direct experience or deep appreciation for the critical role of community organizing and political mobilization, many of today's young activists see only two viable means of effecting change: as the providers of direct service to poor

87. Interview with Miriam Dorsey (Mar. 1, 1996) (on file with the Southern Oral History Program Collection, Southern Historical Collection, University of North Carolina at Chapel Hill Library).

88. Emily Coble, Presentation on Cultural Diversity (Nov. 16, 1995), cited in Berry, supra note 12, at 113 .

89. The authors helped plan this conference, "No Easy Walk," held on December 13-14, 1996.

90. For coverage of the reunion and conference, see Ben Stocking, Groundbreaking North Carolina Fund Provides Inspiration, RALEIGH NEWS \& OBSERVER, Dec. 14, 1996, at A3. 
communities or as power brokers in the public policy arena. That is, in part, no accident. Today's community service movement often reflects lessons learned during the 1960s about the political messiness and unpredictability of volunteerism. Much of the literature on service learning, for instance, focuses more on the moral development of volunteers than on the role of service in contesting political power. Similarly, the enabling legislation for AmeriCorps draws a sharp distinction between service and activism. For example, AmeriCorps volunteers can work to winterize the homes of the poor, but they would violate the terms of their contract by joining with labor unions or other partisan political organizations to demand the enforcement of housing codes. One way to break this impasse is to explore the work of the Fund Volunteers and to recover historical memories of their experiences. Social change, they remind us, requires not only good intentions, but also a willingness to confront and transform existing social and economic relations. ${ }^{91}$

The recovery of historical memory is not just the work of scholars; it is, perhaps more importantly, the work of ordinary citizens as well. Volunteer programs-ranging from Habitat for Humanity to Teach for America and campus service-learning curricula-have proliferated over the last decade. What is striking, however, is how little these undertakings are informed by a knowledge of their predecessors. To fill that void, we need a concerted research effort to explore the history of volunteerism in contemporary America and its effects on individuals, communities, and the larger polity. We also need volunteer and service-learning programs that actively promote an intergenerational dialogue. Only in these ways can we begin to prepare citizen-volunteers who are neither ignorant of the past nor bound by it. ${ }^{92}$

91. In reflecting on the Fund's work, Terry Sanford emphasized the importance of contesting political and economic power:

The [Fund's] first impact was to upset the existing power structures within communities so that changes in the status quo could occur. In most cases, this amounted to radical changes in community relations and activities_-but this we did knowingly, realizing that positive results would occur when existing structures are challenged by the new.

Sanford, supra note 4, at 82. See generally National and Community Service Trust Act of 1993, 42 U.S.C. $\S 12501$ (setting out the prohibition on political activism in the AmeriCorps program); ROBERT COLES, THE CALl OF SERVICE (1993) (discussing community service in the 1990s); COMMISSION ON NATIONAL AND COMMUNITY SERVICE, What YOU CAN Do FOR YOUR COUNTRY (1993); CORPORATION FOR NATIONAL SERVICE, EXPANDING BOUNDARIES: SERVING AND LEARNING (1996); Harris Wofford \& John P. Walters, Should the Federal Government Try to Stimulate Volunteerism Through its National Service Program?, CONG. Q. RES. 6 (Dec. 13, 1996); Jim Zook, National-Service Program Hurt by Politicking Over its Future, 41 CHRON. HigHER EduC. A29 (1995) (discussing AmeriCorps policies and practices); Jill Zuckman, Pared Funding Speeds Passage of National Service, 51 CONG. Q. WKLY. REP. 2160 (Aug. 7, 1993).

92. We have much to learn from other volunteer programs created in the 1960s, especially the Peace Corps, VISTA, and the Appalachian Volunteers. Recent studies of all three programs emphasize the strong relationship between voluntarism and citizenship and the role of volunteers both in the United States and overseas in stretching the capacity of American society to accommodate the views of the poor. See generally FrITZ FISCHER, MAKING THEM LIKE Us: PEACE CORPS Volunteers in the 1960s (1998); Elizabeth CoBbs Hoffman, All You NeEd Is Love: The PEACE CORPS AND THE SPIRIT OF THE 1960S (1998) (describing two recent studies of the Peace Corps). The story of VISTA and AV volunteers in Kentucky and West Virginia is detailed in Marie Tyler McGraw, Staying On: Poverty Warriors in West Virginia, 8 J. AM. Culture 93 (Winter 1985). 
Finally, the story of the North Carolina Fund Volunteers underscores the role of interracial, cross-class alliances in nurturing an inclusive, democratic society. The Fund was surely right in turning its attention after 1965 to the development of indigenous leadership within poor communities, but if the agency made a mistake, it was in setting that goal against a sustained and robust program of student volunteerism. With the shutdown of the Volunteers program, the Fund lost much of its ability to build broad-based support for its work; student activists-both black and white-had fewer opportunities to establish relationships across the racial divide; and the poor found it increasingly difficult to secure the allies they needed to pursue their rights and needs. ${ }^{93}$ As William Julius Wilson and others have argued, these are precisely the kinds of coalition-building and boundary-crossing activities that are needed to combat "the rising inequality in American society." "The true task before us is for the American people, and especially the leaders of the poor, the working classes, the displaced and the marginalized, the downsized and the deskilled, to set aside differences and work together" on a common agenda.

Today, the United States faces problems similar to those confronted by Governor Terry Sanford and his colleagues forty years ago: rapid technological change, growing income inequality, smoldering racial hostilities, and a workforce that is increasingly ill-equipped to meet the challenges of a global economy. In remarks to the North Carolina Fund conference in 1996, Sanford lamented his generation's inability to adequately address these issues. They had not lost the War on Poverty, he insisted, "they [had] abandoned the battlefield." ${ }^{96}$ He was excited to see young activists committed to the ideals of the North Carolina Fund, and he urged them to be more persistent in fighting poverty and racial injustice. For all its limitations, Sanford counseled this new generation of citizen soldiers, the Fund still offered a model of what "could be. ${ }^{97}$

See also Kiffmeyer, supra note 44, at 65.

93. See generally GuION GRIFFIS JOHNSON, VOLUNTEERS IN COMMUNITY SERVICE (1967) (providing a prescient analysis of the need for middle-class volunteers in the fight against poverty). The North Carolina Fund sponsored Johnson's study but seems to have largely ignored her recommendations for a continuation of volunteer programs.

94. William Julius Wilson, The BRidge OVER THE RaCial Divide: Rising Inequality AND COALITION POLITICS 1, 128 (1999).

95. Id. For the value of community service in addressing the fragmentation of American life, see generally STEVE WALdMAN, THE BILl: How the AdVENTURES OF Clinton's NATIONAL SERVICE Bill ReVEAl WHAT IS CORRUPT, COMIC, CYNICAL-AND NOBLE-ABOUT WASHINGTON (1995).

96. Tim Caldwell, Can the Mountaineer Lead the Nation? The Origins of Community Action and the War on Poverty in North Carolina 53 (1995) (unpublished honors thesis, University of North Carolina at Chapel Hill) (on file with North Carolina Collection, University of North Carolina at Chapel Hill Library).

97. Stocking, supra note 90 , at A3. 